money into the hands of countries that are not prepared to spend it effectively, it's going to be just as bad as not spending it at all," says Richard Chaisson, director of the Center for Tuberculosis Research at Johns Hopkins University in Baltimore. Chaisson was invited to serve on the review panel but says that he was unable to do so because of the short notice he was given.

"We have to get it right this time," says Gail Cassell, vice-president for infectious diseases at Eli Lilly, an Indiana-based drug company. "I fear that, because we are expected to do it so rapidly, we won't."

The fund's supporters say they had to move quickly to meet the expectations of donors. "There has been enormous pressure for us to move fast and to show that this can work," says Anders Nordstrom, the fund's interim director. He says that most of the criticism comes from scientists and officials in rich, donor countries, not from the poor countries that have to deal with the diseases.

And while the fund is being attacked for imperfections resulting from its haste to swing into action, other critics argue that its war chest is too puny to tackle the diseases. They point out that Kofi Annan, the secretary general of the United Nations, who pushed for the creation of the fund, has said that between $\$ 7$ billion and $\$ 10$ billion in extra aid is needed to combat AIDS alone.

"The amount of money that donors have contributed so far is quite unimpressive," says Amir Attaran of Harvard University's John F. Kennedy School of Government. But government officials say that the private and public sectors will increase their investment once they see that their initial money has been wisely spent.

\title{
Climate panel unsettled by public battle for top job
}

Jim Giles, London

The Intergovernmental Panel on Climate Change (IPCC) elected a new chair last week - but the nature of the vote has raised questions over the panel's independence.

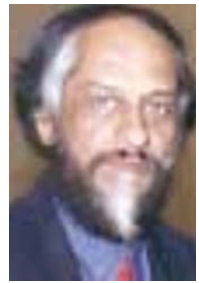

Rajendra Pachauri, director of the Tata Energy Research Institute in New Delhi and vice-chair of the IPCC, beat current chair Robert Watson by 76 votes to 49 in the election held in Geneva on 19April.

Pachauri, an engineer IPCC's new chair: Rajendra Pachauri. and economist by training, is a respected expert in the economics of development. But the public nature of the contest — which is usually settled by consensus during behind-the-scenes negotiations - has posed some uncomfortable questions for the panel, set up in 1988 to advise the world's governments on climate-change issues.

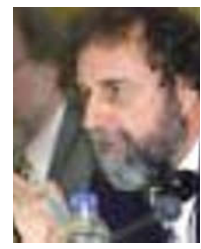

Watson, an ecologist who is chief scientist at the World Bank, had been expected by many climate researchers to serve a second, six-year term. But he was not renominated for the Robert Watson: position by the United expected by many to win. States, which backed his initial candidacy in 1996 (see Nature 416, 251; 2002). He eventually received his nomination from Portugal and New Zealand, after the official 15 March nomination deadline had passed.
Watson's former role as associate director for environment at the White House Office of Science and Technology Policy under President Bill Clinton is thought to have deterred the Bush administration from putting him forward. But evidence has also emerged that ExxonMobil, the US oil company, lobbied the administration not to renominate Watson.

The campaign against him continued at the election meeting in Geneva. "Oil-industry representatives were there lobbying for Pachauri," says Bert Metz, a climate-policy expert at the National Institute of Public Health and the Environment in Bilthoven, the Netherlands, and co-chair of the IPCC working group on mitigating climate change.

Despite the split, IPCC scientists are keen to stress that Pachauri will have their goodwill. Michael Grubb, a climate-change and energy-policy specialist at Imperial College, London, rates Pachauri as extremely capable. "The only worrying thing is the manner in which he was elected," he says.

Pachauri will now have to guide the IPCC towards its fourth climate-change report, due in 2007. Researchers say that the panel's three working groups, which cover climate science, the impact of climate change and the steps that can be taken to mitigate it, respectively, are all in good shape. "The election won't cause lasting damage," says John Houghton of the Hadley Centre for Climate Prediction and Research in Bracknell, west of London, who stepped down as chair of the climate-science group at the elections. "All the groups are in very good hands."

\section{Japan plots course for university on naval-base island}

\section{David Cyranoski, Tokyo}

Japan is pulling into focus its plans for a graduate university that will conduct all of its research and lectures in English.

The first meeting of an international review committee for the project is set to take place on 26-27 April in Santa Monica, California, where leading US scholars, including David Baltimore, president of the California Institute of Technology, will offer their advice.

The university is to be based on the poor, southern island of Okinawa, and will focus on biosciences and information technology. Supporters of the project hope that it will energize a local economy that has largely depended on a locally unpopular US naval base. But some researchers suggest that the island's remote location will make the facility less attractive to potential recruits.

The plan is being championed by Koji Omi, an influential politician who is minister for both the Okinawa region and for national science and technology policy. He says that a lack of English language skills is holding back Japan's science. “I couldn't believe it, but you can get $\mathrm{PhD}$ in a science from many of Japan's universities without knowing English," he says.

Omi wants the college to be a world-class facility. "It will be a university at the very highest level internationally," he says. He hopes to attract 500 research staff and 500 graduate students - more than half of them from foreign countries.

But some researchers are sceptical. "I have serious doubts about whether people will come," says Shigeru Ohde, a marine chemist at the University of the Ryukyus outside Okinawa's capital, Naha. "Why would they come here to study life sciences or IT? Those fields can be studied anywhere." Critics also fear that the project will run out of steam should Omi leave office.

The plan is expected to feature in next year's budget, which will be presented by the government in December. Current estimates for construction costs run from $¥ 20$ billion to $¥ 80$ billion (US\$150 million to $\$ 600$ million), plus $¥ 20$ billion annually for operations. The university is likely to be established as a private institution with strong government support, avoiding the red tape involved in setting up a new public university. 